\title{
WORK IS WHERE HOME IS, OR VICE VERSA? A MULTI-STAKEHOLDER LENS ON NURTURING RELATIONSHIPS FOR THRIVING
}

\author{
Katarina Katja Mihelič \\ University of Ljubljana School of Economics and Business, Slovenia \\ katja.mihelic@ef.uni-lj.si \\ Ajda Merkuž \\ University of Ljubljana School of Economics and Business, Slovenia \\ ajda.merkuz@ef.uni-lj.si \\ Jose Aldo Valencia Hernandez \\ National University of Ireland, Maynooth University, Ireland \\ aldo.valencia@mu.ie \\ Diellza Gashi Tresi \\ Kolegji Riinvest, Kosovo \\ diellzag@gmail.com
}

\begin{abstract}
Since the beginning of the pandemic, working from home has become the prevalent way of working for many employees around the world. Consequently, the nature of daily interactions that previously were taken for granted has changed profoundly, affecting the quality of the work experience. Pursuing connections rather than disconnecting oneself from others can be a purposeful act leading to a positive work experience and thriving. However, there is limited research available about how to thrive while working remotely. Drawing on the micro-organizational literature, this paper presents a framework for individual thriving while working from a home office by nurturing relationships with various stakeholders. Guided by theory on relationships, thriving, and individual accounts of relationship challenges while working from home during the pandemic, we propose strategies for maintaining fruitful relationships in circumstances characterized by uncertainty, anxiety, and loneliness. We argue that employees can be the designers of the following high-quality relationships, which may transform their remote work experience: the relationship with self, with colleagues, with leaders, and with one's partner and family. In this way we make theoretical contributions to Spreitzer et al.'s model of employee thriving.
\end{abstract}

Keywords: working from home, remote work, relationships, thriving, strategies

\section{Acknowledgement}

We gratefully acknowledge funding received from the European Union's Horizon 2020 Research and Innovation program under Marie Sklodowska-Curie grant agreement number 734824 that facilitated the writing of this paper. 
Katarina Katja Mihelič, Ajda Merkuž, Jose Aldo Valencia Hernandez, Diellza Gashi Tresi: Work is Where Home is, or Vice Versa? A Multi-Stakeholder Lens on Nurturing Relationships for Thriving

\section{INTRODUCTION}

In 2020 the volatility, uncertainty, complexity and ambiguity (VUCA) world of work obtained a new meaning when working from home (WFH) becoming a requirement for many and not simply a matter of personal preference. Whereas in 2019 only $5.4 \%$ of EU citizens worked from home (Eurostat, 2020), in 2020 the social distancing measures required for the COVID-19 pandemic forced many to cease going to an office and to set up a permanent workspace at home. This exacerbated the characteristics of the pre-COVID19 contemporary workplace such as constant connectivity, expectations to respond quickly, and blurring of boundaries between work and nonwork (Kolb, Caza, \& Collins, 2012; Mazmanian, 2013). Anecdotal evidence indicates that the speed of working while at home actually has increased, alongside a spike in the number of virtual meetings, making Zoom fatigue a real-life phenomenon (Fosslien \& Duffy, 2020).

Although remote working, which refers to performing work at a location that is not a company office (including working from home and working from anywhere) brings benefits in terms of improved productivity, well-being, job satisfaction, and commitment (Choudhury, 2020; Felstead \& Henseke, 2017), evidence points to various drawbacks that prevent employees from thriving under such conditions-for example, the intensification of work, the difficulty of switching off (Felstead \& Henseke, 2017), and negative interference with regard to the twin spheres of home and work (Wang, Liu, Qian, \& Parker, 2021) along with the related strain (Perry, Rubino, \& Hunter, 2018). Another consequence is reflected in the reduced number of face-to-face interactions with colleagues, leaders, and business partners. With COVID-19 and lockdowns, which forced individuals to work exclusively from home, the number of daily interactions in work as well as non work social circles has been drastically reduced, and thus loneliness has become a major mental health concern (Killgore, Cloonen, Taylor, \& Dailey, 2020), because loneliness, alongside social isolation, leads to depression, cognitive decline, and cardiovascular disease (Smith \& Lim, 2020). Therefore, it is important to consider how social interactions in particular could contribute to effective job performance and thriving, and thus feelings of vitality and learning, while working from home.
This paper developed, through a multi-stakeholder lens, a framework for managing relationships while WFH in order for individuals to thrive. The proposed framework is grounded theoretically in Spreitzer et al.'s model of thriving (Spreitzer, Sutcliffe, Dutton, Sonenshein, \& Grant, 2005). To specify the key relationships and the accompanying challenges while WFH, we analyzed comments posted on LinkedIn threads about two articles that were published during the second wave of the pandemic. Based on that, we outlined evidence-based strategies for nurturing relationships with the self, with colleagues, with leaders, and with one's partner and family.

This focus on such relationships is timely, because COVID-19 has demanded social isolation, and with this, feelings of social awkwardness have increased (Murphy, 2020). Hence, we need to draw attention to how to nurture relationships in order to build the social skills muscle and thrive in a home office. Although organizations can implement systems and adopt routines to support employees $\mathrm{WFH}^{1}$, employees themselves play a pivotal role as co-designers of fruitful work and nonwork relationships. In other words, a focus on employees, which we adopt in this paper, is essential in order to facilitate productive and psychologically healthy WFH. Obtaining evidence-based recommendations for how best to do this also is important because the percentage of workers permanently WFH is projected to rise to 34\% globally in 2021 (Chavez-Dreyfuss, 2020).

\section{THEORETICAL BACKGROUND}

\subsection{A multi-stakeholder framework for thriving while WFH}

Thriving at work is a "psychological state in which individuals experience both a sense of vitality and a sense of learning at work" (Spreitzer et al., 2005, p. 538). But why is work-related thriving important while WFH? Because in the work

\footnotetext{
1 Throughout the paper, we refer to remote work, which is done exclusively from home, as often occurred in the first and second waves of the COVID-19 pandemic, and therefore most of the aforementioned relationships need to be maintained virtually.
} 
domain, it increases work engagement (Abid, Sajjad, Elahi, Farooqi, \& Nisar, 2018), job performance (Elahi, Abid, Arya, \& Farooqi, 2020), and job satisfaction (Zhai, Wang, \& Weadon, 2020). Consequently, it helps individuals increase their positive attitudes toward self-development (Kleine, Rudolph, \& Zacher, 2019) and well-being (Yousaf, Abid, Butt, llyas, \& Ahmed, 2019). Because COVID-19 took a great toll on the latter, by facilitating thriving, people can increase their well-being and overcome the strain caused by WFH. Specifically, WFH has altered working relationships as people interact only digitally, making relationships more formal and less spontaneous, and interactions are limited to seeing only a person's face on a computer screen in the form of a small image.

Because the nature of relationships is profoundly different while WFH, we propose a framework which outlines four human pillars of thriving in a home office, namely four crucial relationships that employees WFH nurture and that are considered to be drivers of thriving. This framework is grounded theoretically in the existing literature that views relationships that are energy-giving (Dutton \& Heaphy, 2003) as one of the key elements for employee thriving in the workplace (Feeney \& Collins, 2015; Spreitzer et al., 2005). Specifically, we build on the socially embedded model of thriving at work (Spreitzer et al., 2005), which presents the dynamics of social systems and dynamic interactions between individuals. In turn, it helps employees to experience vitality and learning. The model focuses on the unit contextual features (e.g., decision-making discretion, broad information sharing, and a climate of trust and respect) and resources (e.g., knowledge, positive meaning, positive affective resources, and relational resources) that are produced in work context, which fuel the engine of thriving: individual agentic work behaviors (Spreitzer et al., 2005). The authors of the model presented task focus, exploration, and heedful relating as agentic work behaviors in the model, and together they help individuals to feel active and purposeful (Spreitzer et al., 2005). This paper focuses on heedful relating through energy-giving relationships from different relational resources (Riaz, Xu, \& Hussain, 2020).
When employees are relating heedfully, they demonstrate understanding of how their job fits with those of others at work in order to achieve team or organizational goals (Spreitzer et al., 2005). Through heedful relating, individuals become more conscious, learn more from colleagues, and boost their energy through interrelated work (Riaz et al., 2020). Only a handful of studies have addressed heedful relating specifically. These provided evidence that perceived organizational support (Abid, Zahra, \& Ahmed, 2016), support climate, psychological capital (Paterson, Luthan, \& Jeung, 2014), servant leadership (Usman et al., 2020b), and abusive supervision (Usman et al., 2020a) affect heedful relating. Moreover, in addition to its effect on thriving at work, which has been proven repeatedly (Paterson et al., 2014; Sia \& Duari, 2018; Usman et al., 2020a; Usman et al., 2020b), Abid et al. (2016) showed that heedful relating mitigates the effects of turnover intentions in the organization.

Relational ties at work, especially during the pandemic, can be an important source of employee energy (Gerbasi, Porath, Parker, Spreitzer, \& Cross, 2015). An interrelated working environment and high-quality relationships stimulate heedful relating, helping employees through sharing knowledge (Dutton \& Heaphy, 2003) and providing an opportunity to learn from each other (Riaz et al., 2020). The connectivity among employees further helps to promote a sense of vitality as employees become more energized due to the social support (Carmeli \& Spritzer, 2009). Moreover, these agentic behaviors foster collaboration and elevate feelings of togetherness, community, and proximity through care, mutual respect, and offering support (Carmeli \& Russo, 2016), and in turn may contribute to lessfrequent feelings of loneliness caused by the physical separation from colleagues at work. By engaging in micromoves such as small acts of kindness and gratitude, employees can demonstrate care. Attentive relating to others is associated with vitality (Dutton \& Heaphy, 2003), and through maintaining positive relationships, work performance is improved (Carmeli \& Spreitzer, 2009), along with well-being and thriving (Carmeli \& Russo, 2016). 
Katarina Katja Mihelič, Ajda Merkuž, Jose Aldo Valencia Hernandez, Diellza Gashi Tresi: Work is Where Home is, or Vice Versa? A Multi-Stakeholder Lens on Nurturing Relationships for Thriving

\section{METHODOLOGY}

This study answers the following research questions:

RQ1: Which are the key relationships while WFH and how are they affected?

RQ2: Which strategies facilitate thriving while WFH through nurturing each of the respective relationships?

To answer the first research question, namely to specify the different stakeholders' and employees' current sentiments while WFH, we collected and analyzed LinkedIn comments on two articles ${ }^{2}$ that were published during the second wave of the pandemic. These comments are public and can be accessed online. We employed thematic analysis to analyze the comments. The choice of articles was guided by the fact that they needed to capture both the work domain and the home domain, which are intertwined when WFH, and they needed to provide personal accounts related to maintaining relationships while WFH. This allowed us to gain insight into the relevant stakeholders that commenters mentioned, as well as into their struggles pertaining to their efforts to nurture connections with different people. Furthermore, we focused on the two articles due to the level of traction received and diversity of comments related to the WFH experience and how it has affected the commenters' relationships. In the analysis, we looked for specific mentions of managing relationships with different stakeholders while WFH during

2 https://www.economist.com/graphic-detail/2020/11/ 24/people-are-working-longer-hours-during-the-pandemic?utm_campaign=the-economist-today\& utm_medium $=$ newsletter\&utm_source=salesforcemarketing-cloud\&utm_term $=2020-11-25 \& u t m$ _content=article-link-4\&etear=nl_today_4.

Comments posted on

https://www.linkedin.com/feed/update/urn:li:activity:6739222167185047552/

https://qz.com/work/1923220/esther-perel-gianpieropetriglieri-on-the-loss-of-the-physical-office/amp/. Comments posted on

https://www.linkedin.com/feed/news/why-you-mightmiss-the-office-4265681/ the pandemic. At the moment of data collection, both articles together had received more than 2,500 likes and 550 comments by Linkedln users. From the 550 comments analyzed, some comments expressed agreement with the authors, a group of comments stated that WFH actually worked for the commenters, and a large number of comments (more than 300) expressed the struggles faced with managing relationships while WFH. Our analysis focused on the 300 comments that expressed struggles with managing relationships with stakeholders while WFH. In times when social connections are involuntarily reduced to a minimum due to COVID-19, fostering virtual connections with colleagues at work and nonvirtual connections with family may be a fundamental mechanism to facilitate thriving while WFH.

\section{RESULTS}

The first article describes how employees WFH are working longer hours, and the second article explores the negative impacts of eliminating office space. After publication on The Economist and Quartz websites, respectively, active LinkedIn users commented by describing their personal viewpoints and daily struggles. When analyzing the comments, we focused on longer comments, which went beyond simply praising the article or agreeing with its content. Regarding the first research question, the authors individually read through the comments and identified the following stakeholders: self (the employee WFH), colleagues from work, leaders and supervisors, and significant others and children. We dubbed these human pillars of thriving, which refer to relationships with proximal players in the work and nonwork realms and reflect a multi-stakeholder perspective (Figure 1). Next, we analyzed employees' personal accounts related to maintaining their work and nonwork relationships. Specifically, we individually searched for statements related to challenges, struggles, and attitudes toward each of the relationships. The personal accounts (Tables 1-4) motivated our search for evidence-based strategies. The following comment on one of the articles succinctly captures the state of living and the relevance of this topic for academic research: 
Living at work is how it is currently. It's been extremely difficult at times when it's all work and no play, no socializing and no human connection. Psychologically I've never known a bigger test on my mental health and I'm sure this is a silent disease.

The following sections (1) present each of the identified relationships in terms of the quotations representing the attitudes related to the particular relationship (RQ1), and (2) offer evidence-based strategies for thriving, whereby the individual designs nurturing relationships with each of the stakeholders in question (RQ2). We propose that through a systematic approach to managing relationships, employees themselves can contribute proactively to sustained thriving even in trying times.

\subsection{Relationship with self}

The increased demands, constant connectivity (Mazmanian, 2013), and numerous phone and video calls, coupled with prolonged working hours along with the fear of missing out can cause stressful interactions with colleagues, leaders, partners, and family members. To facilitate positive interactions with others (Carmeli \& Russo, 2016), one first needs to consider the relationship with oneself. Table 1 reflects the sentiment and self-related challenges while WFH. To move from surviving to thriving while WFH, an employee could first adopt the strategy of building self-compassion competence (Neff, 2003). Self-compassion is an individual's view of themselves, which "involves being touched by

Figure 1: A framework of human pillars facilitating thriving in a home office

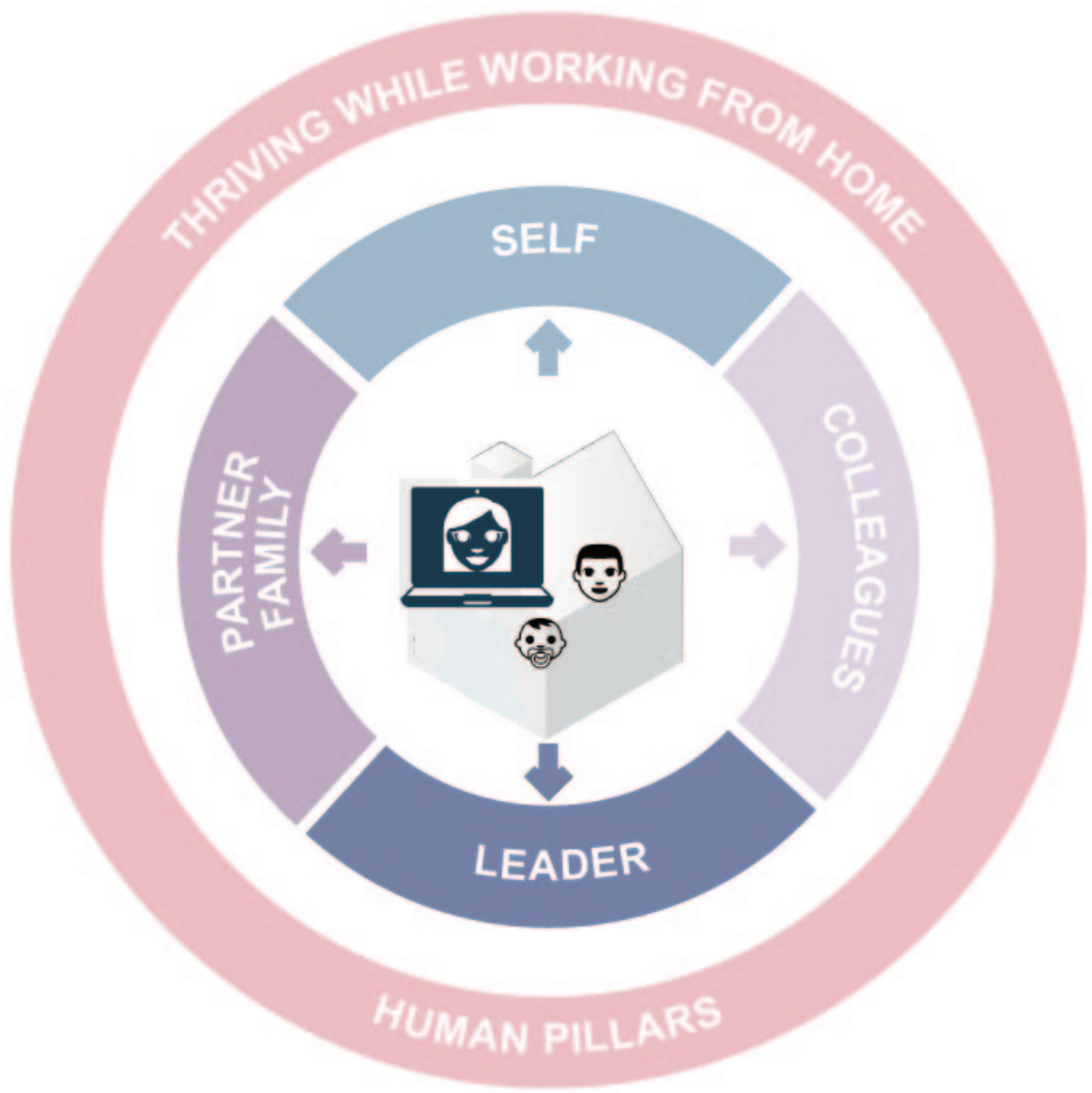

Source: Own work 
Katarina Katja Mihelič, Ajda Merkuž, Jose Aldo Valencia Hernandez, Diellza Gashi Tresi: Work is Where Home is, or Vice Versa? A Multi-Stakeholder Lens on Nurturing Relationships for Thriving

and open to one's own suffering, not avoiding or disconnecting from it, generating the desire to alleviate one's suffering and to heal oneself with kindness" (Neff, 2003, p. 87). It also entails a nonjudgmental stance toward one's pain, suffering, and failures.

\section{Table 1: Relationship with self while WFH: illustrative quotations}

"It is easy to find oneself working longer hours and weekends
(I just checked my e-mail and did some work on Sunday after
Thanksgiving for example)."
"My boundaries are blurred now that work is home and home is
work."
"I often catch myself feeling guilty if I'm not answering emails at
9pm cause...well, I'm home anyway, so I'm not doing anything
else, right?"
"Starting early, few breaks, back to back on calls, late hours. A
daily struggle to keep a boundary between work and home life."
"My working hours have increased by at least 30 mins and usually
more. During those hours I have not taken enough frequent
breaks from screen time, [...], resulting in a stressful role being
even more demanding."

Self-compassion rather than self-blame is important in times of adversity and high workload. When WFH the high expectations related to work (e.g., telepressure, the need to respond quickly to incoming emails, and working until late in the evening), at times can be self-imposed rather than organizationally demanded (Grawitch, Werth, Palmer, Erb, \& Lavigne, 2018). This means that an employee on their own initiative creates a routine of long working hours, causing overwork, or gradually increases their working day by picking up such cues from the supervisor (i.e., social contagion) (Afota, Ollier-Malaterre, \& Vandenberghe, 2019). Both cause stress, which in turn negatively affects thriving (Kleine et al., 2019). Similarly, perfectionism about work can lead to depressive symptoms (Gluschkoff et al., 2017). Self-compassion here serves as a resource that reduces depression and anxiety (de Souza, Policarpo, \& Hutz, 2020).

Self-compassion has three components: (1) self-kindness in times of failure or pain; (2) common humanity/connection, i.e., viewing one's own experience as a part of a bigger picture; and (3) mindful- ness, i.e., not letting painful thoughts overwhelm one, but rather accepting them as they are (Neff, 2003). When WFH, self-compassion can protect an individual from negative thoughts and potential persistent feelings of "never working long enough." Strategies for building self-compassion include the compassionate mind training (CMT) program (Gilbert \& Procter, 2006), which is designed to help an individual accept their emotions with a compassionate attitude. Next are strategies to increase selfcompassion through mindfulness exercises, which include practicing short micro-meditations multiple times a day, longer sitting and walking meditations with the help of apps, establishing daily yoga routines, and pranayama breathing practices. While $\mathrm{WFH}$, individuals also can engage in five mindfulness-based behaviors (i.e., behavioral self-monitoring), as suggested by Kiburz, Allen, and French (2017): dismissing thoughts and bringing the mind back to the present moment, focusing on breathing, noticing the breath moving through different body parts, embracing the sensations in one's body, and walking rather than rushing through the day. The exercise of behavioral self-monitoring involves first tracking the frequency of performing such behaviors in a given week, and then setting goals to increase each of them.

When WFH, the boundaries between a person's work and nonwork lives become nonexistent due to the fact that the two domains are physically intertwined. Moreover, technology has enabled working anytime, not just anywhere, which leads to overwork (Mazmanian, 2013). With this, it is important to be mindful of one's working hours and carefully craft a boundary management style. There are said to be three types of people in terms of preferences for combining work and other realms of life. Segmentors prefer to keep their professional and private lives separate, tend not to bring work home or discuss private matters with colleagues, and even keep separate devices for work and personal matters (Ashforth, Kreiner, \& Fugate, 2000). Integrators like to intertwine the two, and do not mind performing a job task in the evening and tending to a family phone call at work. They also transition more easily between work and nonwork roles (Rothbard, 2020). Finally, volleyers tend to switch between the two realms (Kossek \& Lautsch, 2008). 
With the need to work from home due to COVID-19, many employees were forced to adopt an integrator mindset in the physical sense, with segmentors facing a significant challenge. However, integrators also tend to experience challenges in WFH, including those related to more undesired interruptions (Ashforth et al., 2000). To thrive while WFH, it is important to create temporal and spatial boundaries, which may include establishing and sticking to clear working hours, as well as negotiating them with one's employer and family members (Rothbard, 2020); and adopting a routine of dressing for work and dressing casually when work ends (Rothbard, 2020). With regard to the latter point, creating routines helps one mentally transition between work and nonwork (Shockley \& Clark, 2020). These are referred to as routinized role transitions, which become easier over time as employees develop transition scripts (Ashforth et al., 2000). Rites of separation/transition, as Ashforth et al. (2000) call them, may include having a cup of coffee, listening to a favorite work-related podcast. or planning the day ahead before starting work. Similarly, at the end of the workday, taking a quick walk (Shockley \& Clark, 2020) or riding on a bicycle can serve as psychological momentum which helps one transition back to the nonwork role. Employees also could be asked to prepare their to-do list for the next day or rate how their day went to ease the transition to the nonwork role (Bass, 2020), because this will help with switching off and beginning the process of recovery, as well as enabling one to focus more on other life roles. In terms of creating spatial boundaries, segmentors are advised to set up a home office which should be the only space in which they perform their job duties. When the workday ends, the door to this office is shut, and this serves as a signal that leisure time, or another part of nonwork, has begun. Finally, it is advisable to develop a sense of tolerance to intrusions from family members (e.g., children needing help, and children or pets appearing in front of a camera during a meeting). Practicing self-compassion toward both work and family roles is related positively to more satisfaction and less burnout in both these roles (Nicklin, Seguin, \& Flaherty, 2019). This is particularly important in times of significant changes, such as the move from a regular office to working exclusively from home during the first lockdown.

\subsection{Relationships with colleagues}

Colleagues are a fundamental source of support for successful work performance (Collins, Hislop, \& Cartwright, 2016), as positive interactions with colleagues increase learning and knowledge (Paterson et al., 2014) through the experience and vitality thus gained (Carmeli \& Spreitzer, 2009), thereby impacting thriving. That said, WFH alters both the frequency as well as method of these relationships. Specifically, it decreases opportunities for personal conversations and sharing of experiences and knowledge, and makes reciprocal norms difficult to establish (Lippe \& Lippényi, 2019). Due to working at different locations (i.e., being physically separated) and the inability to directly pick up the cues that a colleague is facing a problem, WFH also has inhibited helping and prosocial behaviors (Kniffin et al., 2020), thus minimizing the opportunities to learn from colleagues. Table 2 reflects the sentiment and challenges faced in nurturing relationships with colleagues while WFH. It is important to facilitate building positive relationships among colleagues in order to enable thriving while WFH, and such interactions can be co-created by employees by implementing specific strategies.

\section{Table 2: Relationship with colleagues while WFH: illustrative quotations}

\footnotetext{
"Virtually collaborating with the team is a bit different and takes quite a lot of time to understand your colleagues, the way they like to work, the norms they follow, the frequency with which the entire team operates."

"You can't pull up a chair next to your co-worker and solve a problem immediately. The feel of accomplishment is less because no one is around you to share that excitement. Just basic human interaction, the background noise, the city views, lunch walks."

"Definitely missing out on social interactions and water-cooler conservations! Now it's just Skype calls or either chasing your co-worker over phone calls if you have something to work together on."

"I also miss the social interaction and the informality of an In person meeting for tea, drinks, lunch where a lot more gets said than the formality of virtual coffee/tea sessions."

"There is also the human factor, where personal interaction with colleagues is a much more enjoyable experience than the odd person posting something 'humorous' on Skype."
} 
An employee could begin by practicing informal one-on-one chats with colleagues (White, 2015) via phone, in which they can talk and share what happened during the day and any issues that they have faced. They can use these brief meetings to share knowledge, coordinate ongoing work tasks, and ensure that work runs smoothly without unnecessary delays. This will help both individuals feel less lonely, energize them, and promote a steady flow of information, which can lead to increased learning and also vitality. These brief sessions should not be formal or involve many people, but rather should involve only two people at a time. Another strategy is for employees to eat lunch together via a video connection, during which they can talk about their families, hobbies, and other personal matters (Knight, 2020). During these virtual get-togethers, colleagues also could share their experiences and stories about how they are managing the challenges of WFH, both professional and personal, which can result in learning, and hence in thriving. Next, colleagues could organize virtual exercise sessions (e.g., yoga, cardio exercises, or stretching) with a gym instructor or a colleague who also is a certified instructor (Liu, 2020). This would enable bonding while maintaining physical stamina and would give the participants more energy. A similar strategy is setting up video chat room links through which employees can gather for morning coffee-type meetings to get ready for the workday (Liu, 2020). In this way, they will feel less lonely while WFH and might not miss chatting in person as much, because this ritual would be done online, creating bonds among colleagues, giving a sense of teamwork and thus that they are in this new situation together (Pollack, 2020).

Employees also could thrive by offering swift help through making themselves available to colleagues by responding to any requests for assistance promptly (Back, 2020). Specifically, if Slack or Basecamp are used for instant messaging, an employee can mark their status as 'available' to show others that they can ask questions if needed (Back, 2020). However, caution should be exercised here, because one should not give the impression of being available anytime during the day and that work-nonwork boundaries can be overstepped at any time. Thus it is best to inform colleagues of one's availability (Back, 2020).
Finally, actually asking for help when needed, even if an employee thinks colleagues are too busy, could improve performance and thrive. It turns out that individuals are more prone to help than is actually assumed (Newark, Bohns, \& Flynn, 2017), and even more so during times of crisis such as the COVID-19 pandemic (Kniffin et al., 2020). Hence, an employee should remember that asking for help solving a particular work issue actually is likely to lead to an improvement in the situation that they are facing (McDermott et al., 2017).

\subsection{Relationship with leaders}

Leaders play an important role in the motivation of employees to complete the required tasks (Andersen, 2016). Passionate and persistent leaders and transformational leaders have been shown to promote employee thriving (Lin, Xian, Li, \& Huang, 2020; Rego et al., 2020). Therefore, fruitful relationships with the leader are crucial for successful employee performance, vitality, and learning. However, because WFH minimizes the direct contact between employee and leader (immediate supervisor), it also affects the quality of the relationship between the two. Namely, WFH increases employee insecurity and leads to working overtime, due to doubting whether the leader will notice and adequately evaluate the results of their work (Raišienè, Rapuano, Varkulevičiūtè, \& Stachová, 2020). WFH also decreases opportunities for contact with leaders and negatively affects trust, the creation of mutual purpose (Grenny \& Maxfield, 2017; Parker, Knight, \& Keller, 2020), and knowledge-sharing opportunities (Lippe \& Lippényi, 2019). In a similar vein, it may impede thriving. Table 3 reflects the sentiment and challenges faced in nurturing relationships with the leader while WFH. Thus, creating a trusting relationship with leaders, particularly while WFH, is very important because it leads to frequent sharing of work-related information (Golden \& Raghuram, 2010), instructions, and advice. Moreover, a fruitful relationship between an employee and a leader might positively impact the leader's well-being and energy, in turn nurturing the relationship even further. Along these lines, employees can implement various strategies to cultivate a thriving relationship with their leaders and supervisors. 
Table 3: Relationship with leaders while WFH: illustrative quotations

"My concern is that if you are working longer hours and not getting the right support and leadership it just amplifies how little investment organisations have made in providing both training and coaching on how to be an effective remote manger/ leader to those supposed to be facilitating new ways of working."

"[Work from home] is always extra hours of work with no additional pay, when you are above to close your laptop you see new email requirement and that's will take 3-5 hours of work. Next thing is your Supervisor asking for the report which came in last night and he will yell at you first thing in the morning."

"The problem is the management is unable to trust its employees when working from home. How have results been achieved, if the employees have not worked, nobody is bothering to look or acknowledge that,"

"Face-to-face social cues and inhibitions are compromised, such that communication becomes fraught with passive aggression, misunderstandings etc."

"My concern is that if you are working longer hours and not getting the right support and leadership it just amplifies how little investment organisations have made in providing both training and coaching on how to be an effective remote manger/ leader to those supposed to be facilitating new ways of working." "[Work from home] is always extra hours of work with no additional pay, when you are above to close your laptop you see new email requirement and that's will take 3-5 hours of work. Next thing is your Supervisor asking for the report which came in last night and he will yell at you first thing in the morning." "The problem is the management is unable to trust its employees when working from home. How have results been achieved, if the employees have not worked, nobody is bothering to look or acknowledge that," "Face-to-face social cues and inhibitions are compromised, such that communication becomes fraught with passive aggression, misunderstandings etc."

Employees could regularly revisit their working regime and discuss it with their leaders. Employee sets specific goals that need to be achieved in a day, building personal standards which then can be used as a form of self-evaluation, accompanied by better self-administration (Bakker, 2017). In the working regime, expectations need to be outlined clearly from the beginning, with both employee and leader offering suggestions. Clarity helps to eliminate potential misinformation and builds trust and cooperation in the relationship (Veil et al., 2020). The self-initiated changes help employees to establish their own job demands and resources, although due to the changes in their job tasks and relationships at work, employees WFH should continuously ask for feedback, guidance, and clarification (Bakker, 2017). Seeking contact via phone, email, or video helps build trust. Here, the proactive stakeholder should be the employee, but it is important that they can count on their leader to offer assistance quickly and provide reassurance when challenges arise in completing tasks. Asking for help to share some of the workload or when the employee does not have adequate competences increases transparency and helps to reach timely solutions. This requires demonstrating vulnerability on the part of the employee.

Bakker (2017) suggested that employees could use reminders that help them focus on accomplishing their work tasks and increasing their self-cueing. At the end of the work week, an employee, via a video call with the leader, can inform them of completed work tasks along with providing a self-assessment of efficiency and effectiveness. The discussion then helps to improve work regimes further, although open communication is highly advised from both sides to enable this (Bakker, 2017; Veil et al., 2020).

Another strategy that employees can undertake is to make pursuing a connection with the leader part of their weekly routine in order to increase their visibility. This can be done by scheduling weekly check-ins via phone to briefly inform the leader of projects that are in progress. These check-ins also can be spontaneous, brief moments of interaction, during which the employee provides information or thanks the leader for support in a particular matter. This means that the employee is proactive in creating a relationship with the leader.

Important milestones and small victories could be a reason for organizing an online celebration with the leader and a work group, enabling informal 
Katarina Katja Mihelič, Ajda Merkuž, Jose Aldo Valencia Hernandez, Diellza Gashi Tresi: Work is Where Home is, or Vice Versa? A Multi-Stakeholder Lens on Nurturing Relationships for Thriving

chatting. Such social events are energy-boosters in times of adversity and challenge and serve to increase morale and perceptions of psychological safety. They also reveal the human side of individuals and the struggles that they with work-family integration, and thus help promote empathy, care, and compassion, which are at the core of contemporary crisis leadership.

\subsection{Relationship with partner}

Stress caused by problems in a marital or other intimate relationship may lead to burnout (Peasley, Hochstein, Britton, Srivastava, \& Stewart, 2020). Conversely, a fruitful relationship with one's partner and family members can help employees feel energized about work, enrich their work experience, and facilitate their path toward learning. Close and meaningful relationships with family members and spouses are a conduit for health, well-being, and thriving (Feeney \& Collins, 2015; Leung, Mukerjee, \& Thurik, 2020), as well as for coping with work-related stress and adversity (Leung et al., 2020). Close relationships also provide opportunities for individual growth and a sense of fulfilment (Feeney \& Collins, 2015).

However, WFH also can negatively affect personal relationships with one's partner and family. With the home being turned into an office, creating boundaries between work and personal life obviously becomes more difficult (Kolb et al., 2012; Mazmanian, 2013). Although an employee is physically present at home, they may not be available to their partner or spouse due to work responsibilities. Furthermore, during COVID-19, the whole family, including children, are likely to be working or studying from home (Dunn, 2020), and this has a profound effect on the quality of the resulting personal relationships. Moreover, WFH means that employees might end up working in unsuitable workspaces and be overloaded with further responsibilities such as household chores and parenting and teaching children (Petriglieri, 2020a). Table 4 reflects the sentiment and challenges faced in nurturing relationships with partner and family while WFH.

\section{Table 4. Relationship with partner/family while WFH: illustrative quotations}

"My husband and I live in a small one-bedroom in a 110-year-old apartment building, and we have noticed how living and working here 24-7 has taken an additional toll on our living space and emotional health."

"I'll be divorced if it carries on much longer, that's for sure."

"We have no room in our place for a separate office; however two of us are supposed to be working from home, one of whom has to make reasonably confidential phone calls to service users."

"The thing is you can't really work from home and do childcare at the same time. Not effectively, one if not both will suffer. Regardless of anyone being irresponsible."

"It's really the online schooling part that distracts from the day. I have my kid's desk set up right next to mine and I have to help her and work. It's been detrimental to my work."

These greater responsibilities while WFH mean that partners can neglect one another (Petriglieri, 2020a), making them feel lonely and less likely to thrive. Therefore, couples could schedule in their calendars two weekly conversations, one related to work-related support and the other to maintaining the household and caregiving responsibilities. By being psychologically available, partners can offer cognitive support by sharing their experience or giving advice on solving a specific work challenge. Scholars advise couples to negotiate household responsibilities (Ward, 2020), which need to be put in writing, communicated clearly, and shared with every member of the household in order to make sure that no one is surprised (Ward, 2020). Experimenting with different divisions of housework and caring contingent on the workload in the current week can lead to solutions that fit a couple well. When children are being home-schooled, as was the case during lockdown, their needs increase and change as well. However, with one or both partners WFH, meeting children's needs might become more difficult, temporarily impairing their relationships with the children.

In situations in which both partners WFH one strategy is for them to acknowledge their significant others' work stress in order to protect their wellbeing (Petriglieri, 2020a). One way to do so is to find the best way to support the partner by clarifying their 
needs so that energy is focused correctly and the aim of trying to help is achieved (Petriglieri, 2020a). To address the issue of loneliness, dual-career couples can allocate a certain amount of time and undivided attention in which they listen to one another at the end or beginning of each working day (Katzman, 2020; Petriglieri, 2020a). Specifically, they can ask one another questions such as "What do you need?" or "Do our WFH arrangements need to be redefined?" (Katzman, 2020). This emotional support will help both partners overcome stress (Zimet, Dahlem, Zimet, \& Farley, 1988), obtain better work-life balance (Russo, Shteigman, \& Carmeli, 2015), understand that they are not alone and that they have someone to talk to and express how they feel, and overall have a partner who supports them and helps them be successful. This also will help employees feel more energized about work. Another strategy is to set the office hours (i.e., working hours) in a calendar so that both partners and/or older children know when someone is working and they do not disturb them. Such a strategy would mean that work is not part of life 24/7 (Katzman, 2020), but rather that there is a dedicated time for work, and what remains can be allocated to joint activities with partners and family members.

A further strategy is to create new rituals with one's partner and family members in order to nurture the relationships and feel more energised
(Katzman, 2020). For example, partners can have lunch together during working hours, do yoga, or engage in micro-meditations (Katzman, 2020). In this way, partners or family members will enjoy some relaxing time together which will help them to momentarily switch off. Along the same lines, to nurture the relationship, couples can work to constantly appreciate one another, understand that they are in this situation together, and acknowledge the roles that each plays in the other's life (Brower, 2020). If both partners make themselves psychologically available to one another, this can increase the positive energy in the relationship (Russo et al., 2015). Simple gestures such as a thank-you text during the day can go a long way toward showing appreciation and support (Brower, 2020).

With regard to nurturing relationships with children, Petriglieri (2020b) proposed that parents need to write on a sheet of paper what each child needs from their parents both practically and emotionally, which expectations can be loosened for each child, and how each child can help the family while the parents are WFH. In this way, children's needs will be acknowledged and parents can better work toward meeting them. Some easy-to-implement strategies pertaining to each of the four focal relationships, which do not require much investment, are presented in Figure 2.

Figure 2: Strategies for nurturing relationships that facilitate thriving while WFH

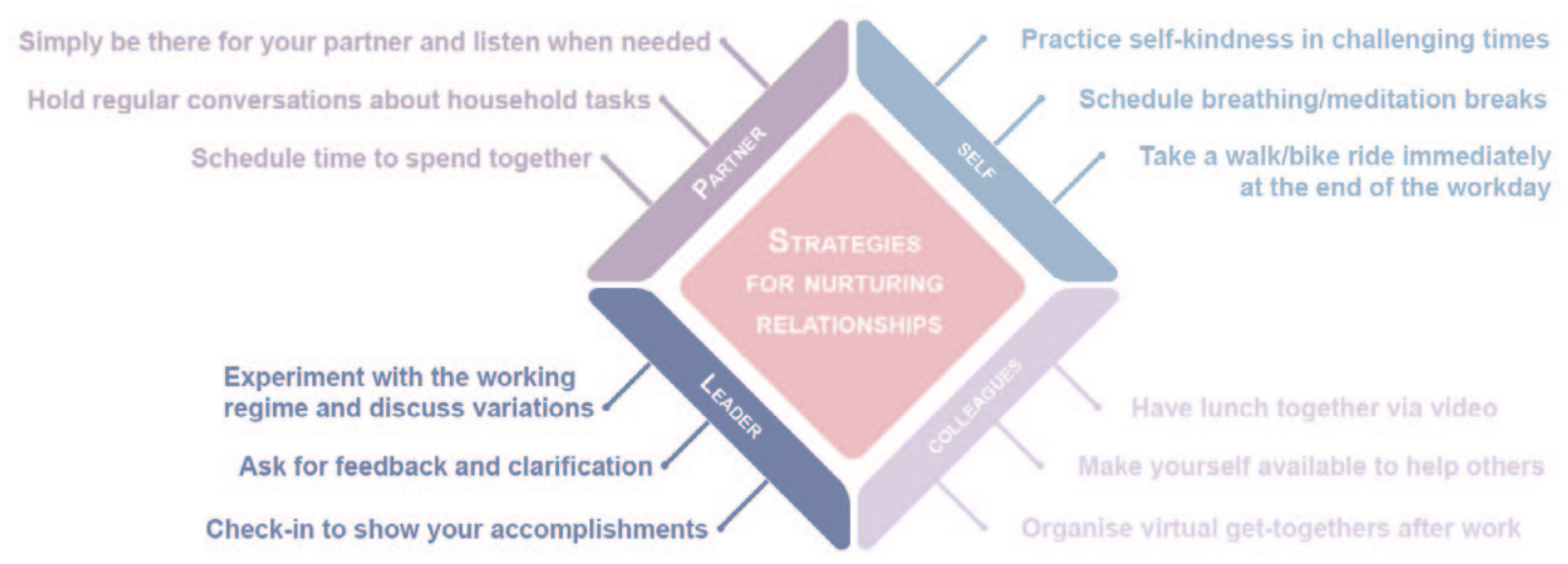

Source: Own work 


\section{DISCUSSION AND CONCLUSION}

\subsection{Theoretical Contributions}

The main contribution of our research is the socially embedded model of thriving. Specifically, we decipher the heedful-relating dimension of the model by explicating which relationships drive employee thriving at work. Firstly, we contributed to the research on heedful relating, as this agentic behavior is very much understudied, with some notable exceptions (e.g., Sia \& Duari, 2018, Usman et al., 2020a; Usman et al., 2020b). Secondly, we provide solutions for how individuals can sustain thriving in unpredictable situations through energizing relationships at work and at home (Riaz et al., 2020). We demonstrated how can different agents and individuals preserve and reshape the conditions which lead to thriving. Thirdly, we explored these relationships in the context of a home office, which thus far has not been done in the thriving literature.

\subsection{Practical Implications}

In terms of practical contributions, we offer specific evidence-based strategies through which employees can nurture the different relationships even in the difficult times of pandemic. Our intention was to bring theory closer to practice and assist employees as they face working and living from the home office and switching from one lifestyle to another practically overnight. It is our hope that the strategies presented herein can assist employees in pursuing stronger connections as part of their daily routines, thereby creating the conditions for their own thriving.

\subsection{Limitations and Future Research}

However, this study has limitations that need to be addressed by further research. Although the comments on the two articles which received much traction on Linkedln were well fitted to our research objectives in the sense that they enabled us to identify different types of relationships that were affected while WFH, there is a possibility of selection bias, such that the users who commented on the two LinkedIn posts were more in- terested in sharing their struggles with managing relationships with different stakeholders than was the average population. To mitigate the selection bias, the framework could be cross-validated on different subsets of highly commented articles. One of the ways to do this would be to search for articles that were published across different waves of the COVID-19 pandemic. Future research on thriving while WFH should focus on samples that are bias-free and ideally representative. Another avenue for research could be diary studies in which each relationship could be observed and analyzed daily.

\subsection{Conclusion}

COVID-19 has profoundly altered the nature of relationships, especially at work. Relationships that previously took place in an office have been transferred to the intimacy of the home. By adopting a multi-stakeholder perspective based on an analysis of employees' personal accounts while WFH, this paper developed a framework for managing relationships while WFH in order for individuals to thrive. Our research was guided by two research questions concerning the key relationships while WFH and how these are affected, as well as by strategies that facilitate thriving while WFH by nurturing each relationship. In answering our research questions, we identified four main relationships, namely relationships with self, colleagues, leader, and partner, which affect employee thriving in a home office. Based on this, we propose evidencebased strategies that can be undertaken to facilitate thriving while WFH by nurturing each of the respective relationships. 


\section{EXTENDED SUMMARY/IZVLEČEK}

S pojavom pandemije je delo od doma postala prevladujoča oblika dela za mnoge zaposlene po svetu. Prav to je močno zaznamovalo tudi naravo interakcij med zaposlenimi, ki smo jih do tedaj imeli za samoumevne. To je vplivalo na kakovost delovnih izkušenj. Zasledovanje povezanosti namesto ločevanja od drugih je lahko zavesten način, ki vodi v pozitivno delovno izkušnjo in uspeh pri delu. Kljub vsemu je literatura precej skopa, ko gre za vprašanje kako uspešno delati od doma. Namen članka je preko mikro-organizacijske literature zasnovati teoretični okvir za individualni uspeh pri delu iz "domače pisarne", in sicer s pomočjo negovanja odnosov s ključnimi deležniki. V nadaljevanju na podlagi teorije odnosov, uspevanja pri delu in zapisov o izzivih $v$ odnosih $v$ času dela od doma med pandemijo, predlagamo na dokazih utemeljene strategije za ohranjanje kakovostnih odnosov v okoliščinah, ki jih zaznamujejo negotovost, tesnoba in osamljenost. Trdimo, da so zaposleni lahko ustvarjalci visoko-kakovostnih odnosov, ki spreminjajo njihovo izkušnjo dela od doma na bolje: odnos s seboj, odnos s sodelavci, odnos z vodjo in odnos z življenjskim partnerjem in družino. Na ta način prispevamo $\mathrm{k}$ uveljavljenemu modelu uspeha pri delu.

\section{REFERENCES}

Abid, G., Sajjad, I., Elahi, N. S., Farooqi, S., \& Nisar, A. (2018). The influence of prosocial motivation and civility on work engagement:The mediating role of thriving at work. Cogent Business \& Management, 5(1), 1-19.

Abid, G., Zahra, I., \& Ahmed, A. (2016). Promoting thriving at work and waning turnover intention: A relational perspective. Future Business Journal, 2(2), 127-137.

Afota, M.C., Ollier-Malaterre, A., \& Vandenberghe, C. (2019). How supervisors set the tone for long hours: Vicarious learning, subordinates' self-motives and the contagion of working hours. Human Resource Management Review, 29(4), 100673.

Andersen, J.A. (2016). An old man and the "sea of leadership". Journal of Leadership Studies, 9(4), 70-81.

Ashforth, B. E., Kreiner, G. E., \& Fugate, M. (2000). All in a Day's Work: Boundaries and Micro Role Transitions. Academy of management review, 25(3), 472-491.

Back, K. (2020, June 29). Creating \& Maintaining Relationships with Remote Co-Workers Blueprint. Virtual Vocations. Retrieved from:

https://www.virtualvocations.com/blog/remoteworking-tips/relationships-with-remote-co-workersblueprint/.

Bakker, A. B. (2017). Strategic and proactive approaches to work engagement. Organizational Dynamics, 46(2), 67-75.
Barber, L., \& Santuzzi, A. (2014). Please Respond ASAP: Workplace Telepressure and Employee Recovery. Journal of Occupational Health Psychology, 20(2), 172-189.

Bass, D. (2020, September 23). Microsoft has a solution for work days that blend into home life: a virtual commute. Fortune.com. Retrieved from https://fortune.com/2020/ 09/23/microsoft-teams-virtual-commute-work-fromhome/

Brower, T. (2020, April 13). Find a balance working from home with your spouse, without driving each other apart. Fast Company. Retrieved from:

https://www.fastcompany.com/90489428/how-tofind-a-balance-working-from-home-with-yourspouse-without-driving-each-other-insane.

Carmeli, A., \& Spreitzer, G.M.(2009). Trust, connectivity, and thriving: Implications for innovative behaviors at work. Journal of Creative Behavior, 43, 169-191.

Carmeli, A., \& Russo, M. (2016). The power of micromoves in cultivating regardful relationships: Implications for work-home enrichment and thriving. Human Resource Management Review, 26(2), 112-124.

Chavez-Dreyfuss, G. (2020). The number of permanent remote workers is set to double in 2021. Retrieved from: https://www.weforum.org/agenda/2020/2010/permanent-remote-workers-pandemic-coronaviruscovid-2019-work-home/.

Choudhury, P. (2020, November-December). Our Workfrom-Anywhere Future. (cover story). Harvard Business Review, 98(6), 58-67. Retrieved from https://hbr.org/ 2020/11/our-work-from-anywhere-future. 
Katarina Katja Mihelič, Ajda Merkuž, Jose Aldo Valencia Hernandez, Diellza Gashi Tresi: Work is Where Home is, or Vice Versa? A Multi-Stakeholder Lens on Nurturing Relationships for Thriving

Collins, A.M., Hislop, D, \&Cartwright, S. (2016). Social Support in the Workplace Between Teleworkers, Office-based Colleagues and Supervisors. New Technology, Work and Employment 31, 161-175.

de Souza, L. K., Policarpo, D., \& Hutz, C. S. (2020). Selfcompassion and symptoms of stress, anxiety, and depression. Trends in Psychology, 1-14.

Dunn, J. (2020, March 2020). How to Work From Home Alongside Your Partner Without Losing It. New York Times. Retrieved from:

https://www.nytimes.com/2020/03/20/parenting/ coronavirus-work-from-home-spouse.html

Dutton, J., \& Heaphy, E. (2003). The power of high quality connections. In K.S.Cameron, J.E. Dutton, \& R.E. Quinn (Eds.), Positive organizational scholarship: foundations of a new discipline (pp. 263-278). San Francisco, CA: Berrett-Koehler.

Elahi, N. S., Abid, G., Arya, B., \& Farooqi, S. (2020). Workplace behavioral antecedents of job performance: mediating role of thriving. The Service Industries Journal, 40(11-12), 755-776.

Eurostat. (2020). How usual is it to work from home? Retrieved from:

https://ec.europa.eu/eurostat/web/products-eurostat-news/-/DDN-20200424-20200421.

Feeney, B. C., \& Collins, N. L. (2015). A new look at social support: A theoretical perspective on thriving through relationships. Personality and Social Psychology Review, 19(2), 113-147.

Felstead, A., \& Henseke, G. (2017). Assessing the growth of remote working and its consequences for effort, well-being and work-life balance. New Technology, Work and Employment, 32(3), 195-212.

Fosslien, L., \& Duffy, M. W. (2020, April 29). How to combat zoom fatigue. Harvard business review. Retrieved from: https://hbr.org/2020/04/how-to-combatzoom-fatigue

Gadeyne, N., Verbruggen, M., Delanoeije, J., \& De Cooman, R. (2018). All wired, all tired? Work-related ICT-use outside work hours and work-to-home conflict: The role of integration preference, integration norms and work demands. Journal of Vocational Behavior, 107, 86-99.

Gerbasi, A., Porath, C. L., Parker, A., Spreitzer, G., \& Cross, R. (2015). Destructive de-energizing relationships: How thriving buffers their effect on performance. Journal of Applied Psychology, 100(5), 1423-1433.

Gilbert, P., \& Procter, S. (2006). Compassionate mind training for people with high shame and self-criticism: Overview and pilot study of a group therapy approach. Clinical Psychology \& Psychotherapy: An International Journal of Theory \& Practice, 13(6), 353-379.
Gluschkoff, K., Elovainio, M., Hintsanen, M., Mullola, S., Pulkki-Råback, L., Keltikangas-Järvinen, L., \& Hintsa, T. (2017). Perfectionism and depressive symptoms: The effects of psychological detachment from work. Personality and individual differences, 116, 186-190.

Golden, T. D., \& Raghuram, S. (2010). Teleworker knowledge sharing and the role of altered relational and technological interactions. Journal of Organizational Behavior, 31(8), 1061-85.

Grawitch, M. J., Werth, P. M., Palmer, S. N., Erb, K. R., \& Lavigne, K. N. (2018). Self-imposed pressure or organizational norms? Further examination of the construct of workplace telepressure. Stress and Health, 34(2), 306-319.

Grenny, J., \& Maxfield, D. (2017, November 2). A Study of 1,100 Employees Found That Remote Workers Feel Shunned and Left Out. Harvard Business Review. Retrieved from: https://hbr.org/2017/11/a-study-of1100-employees-found-that-remote-workers-feel-shu nned-and-left-out.

Katzman, M.A. (2020, March 13). Relationship Survival Strategies for Working From Home When you are literally "in it together." Psychology Today. Retrieved from: https://www.psychologytoday.com/us/blog/connect-first/202003/relationship-survival-strategiesworking-home.

Kiburz, K. M., Allen, T. D., \& French, K. A. (2017). Workfamily conflict and mindfulness: Investigating the effectiveness of a brief training intervention. Journal of Organizational Behavior, 38(7), 1016-1037.

Killgore, W. D., Cloonen, S. A., Taylor, E. C., \& Dailey, N. S. (2020). Loneliness: A signature mental health concern in the era of COVID-19. Psychiatry Research, 113-117.

Kleine, A. K., Rudolph, C. W., \& Zacher, H. (2019). Thriving at work: A meta-analysis. Journal of Organizational Behavior, 40(9-10), 973-999.

Kniffin, K.M., Narayanan, J., Anseel, F., Antonakis, J., Ashford, S.P., Bakker, A.B., . . . van Vugt, M. (2020). COVID19 and the Workplace: Implications, Issues, and Insights for Future Research and Action. Working paper 20-127. American Psychologist. DOI: 10.1037/amp0000716.

Knight, R. (2020, October 7). How to manage a hybrid team. Harvard Business Review. Retrieved from: https://hbr.org/2020/10/how-to-manage-a-hybrid-team.

Kolb, D. G., Caza, A., \& Collins, P. D. (2012). States of connectivity: New questions and new directions. Organization Studies, 33(2), 267-273.

Kossek, E. E., \& Lautsch, B. A. (2008). CEO of me: Creating a life that works in the flexible job age. Upper Saddle River, NJ: Pearson Prentice Hall.

Leung, Y.K., Mukerjee, J., Thurik, R. (2020). The role of family support in work-family balance and subjective well-being of SME owners. Journal of Small Business Management, 58(1), 130-163. 
Lippe, T., \& Lippényi, Z. (2019). Co-workers working from home and individual and team performance. New Technology, Work and Employment, 35, 60-79.

Liu, J. (2020, March 25). Virtual happy hours, team yoga sessions: How coworkers are staying connected while they work from home. CNBNC. Retrieved from: https://www.cnbc.com/2020/03/25/how-coworkersare-staying-connected-while-they-work-fromhome.html

Lin, Cp., Xian, J., Li, B., \& Huang, H. (2020). Transformational Leadership and Employees' Thriving at Work: The Mediating Roles of Challenge-Hindrance Stressors. Frontiers of Psychology,11, 1-19.

Mazmanian, M. (2013). Avoiding the trap of constant connectivity: When congruent frames allow for heterogeneous practices. Academy of Management Journal, 56(5), 1225-1250.

McDermott, R., Cheng, H., Wong, J., Booth, N., Jones, Z., \& Sevig, T. (2017). Hope for help seeking: A positive psychology perspective of psychological help-seeking intentions. The Counseling Psychologist, 1-29.

Murphy, K. (2020, September1). We're All Socially Awkward Now. The New York Times. Retrieved from: https://www.nytimes.com/2020/2009/2001/sundayreview/coronavirus-socially-awkward.html.

Neff, K. (2003). Self-compassion: An alternative conceptualization of a healthy attitude toward oneself. Self and identity, 2(2), 85-101.

Newark, D., Bohns, V., \& Flynn, F. (2017). A helping hand is hard at work: Underestimating help quality. Organizational Behavior and Human Decision Processes, 139, 223-226.

Nicklin, J. M., Seguin, K., \& Flaherty, S. (2019). Positive work-life outcomes: Exploring self compassion and balance. European Journal of Applied Positive Psychology, 3(6), 1-13.

Parker, Sh.K., Knight, C., \& Keller, A. (2020, July 30). Remote Managers Are Having Trust Issues. Harvard Business Review. Retrieved from: https://hbr.org/2020/07/remote-managers-are-having-trust-issues.

Paterson, T. A., Luthans, F., \& Jeung, W. (2014). Thriving at work: Impact of psychological capital and supervisor support. Journal of Organizational Behavior, 35, 434-446.

Peasley, M.C., Hochstein, B., Britton, B.P., Srivastava, R.V., \& Stewart, G.T.(2020). Can't leave it at home? The effects of personal stress on burnout and salesperson performance. Journal of Business Research, 117, 58-70.

Perry, S. J., Rubino, C., \& Hunter, E. M. (2018). Stress in remote work: two studies testing the Demand-Control-Person model. European Journal of Work and Organizational Psychology, 27(5), 577-593.
Petriglieri, J. (2020a, June 4). Don't Let Your Partner's Work Stress Become Your Own. Harvard Business Review. Retrieved from: https://hbr.org/2020/06/dontlet-your-partners-work-stress-become-your-own.

Petriglieri, J. (2020b). Couples That Work @ Home: The Survival Series. Jennifer Petriglieri. Retrieved from: https://www.jpetriglieri.com/couples-that-workhome-the-survival-series.

Pollack, S. (2020, March 18). How to Stay Connected With Your Colleagues Remotely While Working From Home. Workfest. Retrieved from: https://www.zenefits.com/workest/how-to-stay-connected-with-yourcolleagues-while-working-from-home/.

Raišienè, A. G., Rapuano, V., Varkulevičiūtè, K., \& Stachová, K. (2020). Working from Home-Who is Happy? A Survey of Lithuania's Employees during the Covid-19 Quarantine Period. Sustainability, 12(13), 121.doi:10.3390/su12135332

Rego, A., Cavazotte, F., Cunha, M.P., Valverde, C., Meyer, M., \& Giustiniano, L. (2020). Gritty Leaders Promoting Employees' Thriving at Work. Journal of Management, 20(10),1-30.

Riaz, S., Xu, Y., \& Hussain, S. (2020). Role of relational ties in the relationship between thriving at work and innovative work behavior: an empirical study. European Journal of Investigation in Health, Psychology and Education, 10(1), 218-231.

Rothbard, N. P. (2020, July 15). Building work-life boundaries in the WFH era. Harvard Business Review. Retrieved from: https://hbr.org/2020/2007/building-work-lifeboundaries-in-the-wfh-era.

Russo, M., Shteigman, A., \& Carmelic, A. (2015). Workplace and family support and work-life balance: Implications for individual psychological availability and energy at work. The Journal of Positive Psychology, 11(2), 173-188.

Shockley, K. M., \& Clark, M. A. (2020). Work-Family Balance Struggles in the Time of COVID-19. Retrieved from: https://www.siop.org/Research-Publications/Items-ofInterest/ArtMID/19366/ArticleID/3454/Work-FamilyBalance-Struggles-in-the-Time-of-COVID-19?utm_sour ce=Social\&utm_medium=Post\&utm_campaign=RemoteWork.

Sia, S. K., \& Duari, P. (2018). Agentic work behaviour and thriving at work: Role of decision making authority. Benchmarking: An International Journal, 25(8), 1463-5771.

Smith, B. J., \& Lim, M. H. (2020). How the COVID-19 pandemic is focusing attention on loneliness and social isolation. Public Health Research \& Practice, 30(2), e3022008.

Spreitzer, G., Sutcliffe, K., Dutton, J., Sonenshein, S., \& Grant, A. M. (2005). A socially embedded model of thriving at work. Organization Science, 16(5), 537-549. 
Katarina Katja Mihelič, Ajda Merkuž, Jose Aldo Valencia Hernandez, Diellza Gashi Tresi: Work is Where Home is, or Vice Versa? A Multi-Stakeholder Lens on Nurturing Relationships for Thriving

Usman, M., Liu, Y., Zhang, J., Ghani, U., \& Gul, H. (2020a). Why do employees struggle to thrive in the workplace? A look at the impact of abusive supervision. Personnel Review, 1-21.

Usman, M., Liu, Y., Zhang, J., Ghani, U., \& Gul, H. (2020b). Enabling the engine of workplace thriving through servatn leadership: The moderating role of core selfevaluations. Journal of Management \& Organization, 1-19.

Veil, S. R., Anthony, K. E., Sellnow, T. L., Staricek, N., Young, L. E., \& Cupp, P. (2020). Revisiting the best practices in risk and crisis communication: A multi-case analysis. The Handbook of Applied Communication Research, 377-396.

Wang, B., Liu, Y., Qian, J., \& Parker, S. K. (2021) Achieving effective remote working during the COVID-19 pandemic: A work design perspective. Applied psychology, 0, 1-44.

Ward, M. (2020, March 9). How to keep your relationship intact if you're forced to work from home because of the coronavirus outbreak. Business Insider. Retrieved from: https://www.businessinsider.com/does-working-from-home-hurt-a-relationship-what-experts-say2020-2.

White, S.K. (2015, November 25). How to maintain strong relationships with remote workers. $\mathrm{ClO}$. Retrieved from: https://www.cio.com/article/3008872/how-tomaintain-strong-relationships-with-remoteworkers.html.

Yousaf, K., Abid, G., Butt, T. H., Ilyas, S., \& Ahmed, S. (2019). Impact of ethical leadership and thriving at work on psychological well-being of employees: mediating role of voice behaviour. Business, Management and Education, 17(2), 194-217.

Zhai, Q., Wang, S., \& Weadon, H. (2020). Thriving at work as a mediator of the relationship between workplace support and life satisfaction. Journal of Management \& Organization, 26(2), 168-184.

Zimet, G. D., Dahlem, N. W., Zimet, S. G., \& Farley, G. K. (1988). The Multidimensional Scale of Perceived Social Support. Journal of Personality Assessment, 52(1), 30-41. 